\title{
THE ENTRY OF AN EXTREME RIGHT PARTY INTO THE SLOVAK PARLIAMENT AFTER THE 2016 AND 2020 ELECTIONS: THE RETURN OF FASCISTS?
}

\author{
Michal CIRNER \\ Assistant Professor, Institute of Political Sciences, \\ Faculty of Arts, University of Prešov, Prešov, Slovakia \\ E-Mail: michal.cirner@unipo.sk \\ Irina DUDINSKÁ \\ Associate Professor, Institute of Political Sciences, \\ Faculty of Arts, University of Prešov, Prešov, Slovakia \\ E-Mail: irina.dudinska@unipo.sk
}

\begin{abstract}
The political party Kotlebovci - People's Party Our Slovakia (Kotlebovci - Ludová strana Naše Slovensko) is a far-right political group in Slovakia. Though the Political Party of Marian Kotleba had previously been dissolved by the Supreme Court of the Slovak Republic, this marginal political party became a parliamentary political formation after the parliamentary elections in March 2016 when fourteen of their members won seats in the 150-member parliament. The Slovak President Andrej Kiska refused to invite its leader, Marian Kotleba, who was labelled as a fascist, to visit the statehouse. The media and analysts also frequently label this political party as extremist or fascist. It is not easy to evaluate the ideological and value orientation of political parties, but there are theoretical concepts presented by relevant authors such as Beyme, Mudde, Drábik and Mair. These ideas form the basis of our study. The study seeks to find the answer to the problematic question of whether or not it is possible to brand this party as (neo)fascist in terms of theory, methodology and terminology. There was a proposal by the General Prosecutor's Office to dissolve the current political party of Marian Kotleba. Therefore it is the responsibility of other social sciences such as political sciences or history, to help the state to intervene against the enemies of democracy and tolerance.
\end{abstract}


Key words: extreme right political party, political extremism and radicalism, Slovak politics, (neo)fascism, Marian Kotleba.

\section{Introduction}

In Slovakia in the early 1990s, the exiles that communists called clerical-fascist, who survived the regime, and their successors, started to mobilise again. The right extremists from the skinhead movement or neo-Nazis meet with the "Old Guard" every year on 14 March at the grave of the president of the Slovak State, Jozef Tiso, who was sentenced and executed in 1947 for war crimes or crimes against humanity. The far right Slovak National Party (Slovenská národná strana), especially while it was led by Ján Slota, was famous for its political agenda built on nationalism and preservation of conservative values, with a refusal to accept a liberal agenda in cultural and ethical issues. This party also played on the "Hungarian card" and the "Roma card" and was always part of the political mainstream. However, the political grouping Kotlebovci - People's Party Our Slovakia, that became a part of parliament after the 2016 and 2020 parliamentary elections, has a completely different past and present. Some media and political analysts label them as fascists and extremists. However it is a question as to whether or not experts can afford to call them such. There are a number of theoretical and methodological problems concerning the classification of such groups. The Slovak specificities, historical background and other matters should be considered. Social sciences can unlikely to provide us with the exact answer, but we will try to find at least some answers. The study would be a success if it engages further discussions on these questions, constructive criticism as well as challenges. It would be a step forward in examining the contemporary far right political scene.

In Slovakia, though we might think we can know in practice what fascism is, its current form confuses us. It is often presented as populism and radicalization or anti-system and a protest political force. Citizens disregard symbolism and open features of fascist ideology. Worse, politicians or the judiciary also cannot agree on the clear signs of neo-fascism. They fail in the moral and legal condemnation of these acts. Furthermore, it is a question as to whether or not to ostracize such political parties when they were democratically elected by citizens. The judiciary still lacks experts on both political and religious extremism. Then there is the issue of freedom of speech, which every judge sees differently. As we know, the enemies of the system often abuse the freedom of speech. Finally, some academics also say that the terms "extremism" or "fascism" are overused.

The past has shown that democracy had the greatest weakness in the sense that extremist or totalitarian opinion streams, protected under the right to freedom of expression, could be presented in a competition of political opinions 
The entry of an extreme right party into the Slovak parlament...

and ideas, and were so successful that their supporters were elected to the legislature, where they could democratically simply remove democratic principles, eventually destroying the democratic face of the country, with a de facto totalitarian environment that had nothing to do with democracy.

If we have to answer the question of whether the Kotleba political party is (neo)fascist, the answer is clearly yes. There are significant evidence, arguments and reasons that this is so. Based on theory and analytical research, we will try to prove this claim.

Our article is divided into questions of methodological clarification of the studied issue. Then we will deal with the terminology and the review of literature on fascism, extreme right and political radicalism and political extremism. In the following part we will describe the specific aspects of the extreme right in Slovakia. We also describe the predecessors of the political party Kotlebovci - LSNS and finally, in the analytical part, we analyse that political party in terms of its value and ideological orientation. In conclusion, we present more arguments for why we believe that LSNS is a fascist political party.

\section{Methodological insertion}

This case study is built on a qualitative methodology. Hanzel (2009) speaks about ontological character of data. According to that, qualitative data is intentionalist and includes values, beliefs and intentions. In social sciences, Drulák (2008) distinguishes between two basic epistemological positions. The former seeks to explain the world and the latter wants to understand the world or interpret it. This directly translates in the methodology. The qualitative methodology is divided into explanatory and interpretative approaches. Our case study chooses the interpretative approach with the aim to reconstruct the subjective or shared meanings that individuals and groups attribute to the reality. The interpretation, being an analysis of these meanings, then allows to understand actions of the individuals and groups examined. Qualitative methodology is highly dependent on the research context and its application is almost always a creative act. Such research is influenced more by subjective abilities and visions of the researcher. However, it is necessary to respect the so-called hermeneutic circle which means that individual parts (for example, parts of the text) cannot be understood without understanding the whole and, vice versa, the whole will not be understood without understanding its individual parts. We approach individual parts with certain presuppositions that are based on ideas about the whole.

The theoretic framework clarifying the conceptual apparatus and characteristics of the far right political groupings, radicalism, extremism (also in the form of (neo)fascism) is, simultaneously to the academic interpretation of the value-ideological base of these subjects from the point of view of social 
scientists (especially historians, sociologists, political philosophers and political scientists), fertile ground for the analytical part of the study, where the identification of values, standards and procedures that can be considered far right plays an important role. It is a basis for examination of the selected political groups.

We agree with many authors (Beyme 1985; Mudde, Mair, 1998; Gallagher, Mair, Laver, 2005; Rybář, 2003; Hloušek, Kopeček, 2010) that the genesis of a political party has an irreplaceable role in assessing political groups. For this reason, we analyse the genealogy and development of Kotleba's political party from its formation.

Rybár (2003) suggests that the so-called voluntarist factor, when the leader or leaders of a new political party set the ideology and programme of the party according to their own preferences is an important element in this discussion. Žuborová (2011) believes that party leaders play an important role within their political parties. They create the overall political image not only in relation to society but also to the other political parties within the system. With the growth of new communication tools, in relation to political communication, the power and dominant position of party leaders proportionally reinforces the growth of the party. Mudde, Mair, 1998; Gallagher, Mair, Laver, 2005; Rybáŕ, 2003; and Hloušek, Kopeček, 2010 consistently consider leadership as a necessary factor to assess when classifying the party into the theoretical concept of party families.

Beyme (1985) prefers an ideological approach more than a programme approach. Using party documents such as statute, general policy, and party vision, we focus on the position of ideology and values. In programme documents, we describe and evaluate the resolutions that can be evaluated according to the theoretical framework. We analyse the election manifesto of the party in the parliamentary elections in 2012 and 2016. We also analyse the political party through its past political decisions and declarations, where we present extracts of real and principal decisions. In some cases, we describe the proposals made by the officials of the political party as an opposition political group or we describe the decisions of party authorities and ideologists, supported by the political party that they represent. A certain extent of subjectification cannot be avoided but again it colours the picture of the behaviour of the political party and its officials in practice.

It is clear that such methodology is not complete. The impact of subjective characteristics of the researcher for data collection and evaluation is possible in a number of respects. The greatest degree of subjectivism may arise when selecting the policies implemented by the political party that may be largely adapted to the preferences of the researcher. Neither can the objective overall evaluation of the study be utterly guaranteed. Therefore, we will not formulate a hypothesis that should be a sort of a statement of belief. We believe that to categorically label the party as fascist, whether the study confirmed or 
The entry of an extreme right party into the Slovak parlament...

rejected the hypothesis would not be absolutely accurate. The truth does not lie somewhere in between since there are so many variables that it is likely that the answer will be in a latent form. The reader should not find the answer between the lines. In this study the journey is the destination.

\section{On literature review: About (neo)fascism, extreme right, political radicalism and extremism}

Comparative studies of fascism have begun to address its more ideological and cultural dimension. Analysis of so-called generic fascism have actually shifted from a sociological point of view to a more political one in the past twenty years and emphasize that ideology and culture were far more important for the fascists than we had previously thought. The current interest in fascism has undoubtedly been encouraged by Griffin's work The Nature of Fascism, which has sparked many debates, as well as by the contributions of Eatwell and Payne. Definitions as such are never true or false, they can only be viewed with varying degrees of utility and suitability. In particular, a new generation of historians, such as Kallis, Iordachi, Love, Umland, Baker, Shekhovtsov, and Costa Pinto, follow up on Griffin's work. There are several different, often contradictory definitions of the term "fascism". This is mainly due to the fact that there are many different ways to look at fascism: through ideology, through the actions of fascists themselves, through the socioeconomic conditions in which fascism originated. Even the fascist movements, which were based on different national history and traditions and lived in other national realities, are quite different (Drábik, 2014). Mikušovič (2012) presents the term "extreme right" as based on political studies, through two different theories. One is a theory of party families, where far right parties have their own family. Such political parties share their ideological base consisting of the following signs: nationalism, xenophobia, programme of chauvinist social security and a belief in law and order. The second is a theory of extremism that understands the extreme right as an umbrella term involving right-wing radicalism and right-wing extremism.

The resolution of the Council of Europe no. 1344 of 25 September 2003 states that extremism, whatever its nature, is a form of political activity that overtly or covertly rejects the principles of parliamentary democracy, and often bases its ideology and its political practices and conduct on intolerance, exclusion, xenophobia, anti-Semitism and ultra-nationalism. Political extremism is directed against the democratic constitutional state. In democratic countries it is active through political parties, interest groups, social movements and subcultures (Mareš, 2003).

Cas Mudde (1995) claims that the origin of the term right-wing extremism and the studies of right-wing extremism are based on the study of fascism. He defines right-wing extremism as an ideology that contains several 
elements: nationalism, racism, xenophobia, anti-democracy and strong state. Right-wing radicalism has become a collective term for new far right parties and (neo-)fascist and (neo-)Nazi parties. Ignazi (1995) agrees with Mudde in considering fascism as the only ideological body for the extreme right.

The primary criterion that is mentioned most frequently when examining these parties is, according to Mudde (1995), ideology. Most studies examine the ideology of a party solely through an analyse their statutes, party platforms or different party manifestos. However, there are also voices taking the view that these sources of analyses are not satisfactory to understand rightwing extremist parties because these parties cannot and do not want to tactically show their colours. Apart from other aspects, the election manifestos of political parties focus on pleasing their members and voters and on promoting their public image. Behind this "front line" the extremist parties have a far more radical "background" that may be hidden.

However, as Mikušovič (2012a) rightly stresses, not all far right parties can be defined on the basis of their relation to democracy. Some of them absolutely lack any criticism of democratic institutions, nevertheless, they are labelled as the extreme right because of their rhetoric and ideology, in which different traditional extreme right issues are present. These parties are then characterised on the basis of their political style and represent ultra-right-wing populism.

A Slovak expert on this topic, Tomáš Nociar (2016), published an article in this context entitled "Political scientist's guide through a "terminological chaos": Terminology, characterisation and conceptualization of the far-right ideological family". Based on prevailing interpretations as well as interpretations of individual terms defined by Cas Mudde, he conceptualized the far right ideological family according to its ideological family tree. The trunk consists of the individual ideological features of the extreme right and the crown consists of the individual branches of the extreme right. The most common concept presents the extreme right comprising of nativism (xenophobic nationalism) and authoritarianism. The extreme right is further divided into the radical right (nativism, authoritarianism, anti-liberaldemocratic sentiment); populistic to the radical right (nativism, authoritarianism, anti-liberal-democratic sentiment, other populistic traits dividing society between "pure people" and "corrupted elites"); the extreme right (nativism, authoritarianism, antidemocratic sentiment); neo-fascism (nativism, authoritarianism, antidemocratic sentiment, ideological continuity with the fascist regime); neo-Nazism (nativism, authoritarianism, antidemocratic sentiment, ideological continuity with the Nazi regime biological racism and anti-Semitism). For the sake of heterogeneity Nociar believes that the extreme right is the most suitable term to refer to these political groups. 
The political scientist Mareš (2003), when discussing terminology, draws attention to the problem of the overuse of the term "extremist" in the media discourse. In many cases the mainstream parties, in order to deliberately delegitimize some groups, label them as "extreme". Therefore, Mareš suggests using the term "extreme right" for extremist and radical formations. Eremina and Seredenko (2015) even suggest the term "socially dangerous" be used when discussing these political parties.

In this study it is important to give more detailed attention to the term (neo)fascism and the contemporary view of it. Kopeček (2007) defines fascism as a negation of rationalism, progress, freedom and equality, and generally everything connected to the year of 1789, which is associated with the Great French Revolution and subsequent changes in society. Fascism was also characterised by rejection of capitalism, liberalism, communism, democracy and the parliamentary system. Fascism features the idealization of the nation and the constant "struggle" of nations for supremacy within the socioDarwinian notion as the fundamental impulse of history. Fascism is also characterised by applying the leadership principle and the cult of the leader, heroism and corporatism functioning within society.

Fascism is according to Drábik (2019, p. 27) "a type of revolutionary nationalism characterized by obsessive notions of the disintegration of society, decadence, and national humiliation. At the same time, it seeks (usually by force) to achieve utopian national rebirth by cleansing the nation of enemies and creating a new political and social order and a new man" For key characteristics of fascism considered Drábik (2019) revolutionary, ultranationalism and racism, ideas about the decline of the society, national rebirth, violence and paramilitarism, cleanse the nation from enemies, introduction of a new order and create a new man.

Karapin (1998) writes that successful far right parties today have organizational and personal connections to pre-1945 fascists or Nazis, adopt programmes that are similar to fascism and seek to resurrect or create fascist regimes. Therefore, they use quasi-fascist appeals to play upon current resentment, such as immigration and unemployment, and try specifically to mobilize middle class support ("petite bourgeoisie").

The historian Copsey (2013) published an interesting article entitled "Fascism... but with an open mind" in which he deals with new forms of fascism or neo-fascism. Upon hearing from a student who declared himself a "fascist but one with an open mind", Copsey asks how "can fascism, a demonized ideology, a by-word for genocide driven by fanaticism possess anything approaching an open-mind? When it comes to understanding developments on the contemporary far right in Western Europe, we have really witnessed the emergence of a "new" breed of fascists" (Copsey, 2013, p. 1). Copsey asks if neo-fascism had adapted itself to the norms of multi-ethnic, liberal-democratic society. By the mid-1990s, growing numbers of political 
scientists were insisting that Western Europe had not experienced any upsurge in "neo-fascism" but the emergence of a new kind of politics entirely, defined as radical right-wing populism. It was proposed that the emergence of exclusionary populist ideology should have absolutely nothing to do with a revival of fascism or "neo-fascism in postmodern guise". What follows is a widely shared belief that the populist radical right is not neo-fascism, but neither is it simply a moderate form of the extreme right. According to Copsey it surely is a mistake to argue that neo-fascism has played a minimal role in defining the ideological and discursive practices of the contemporary far right. The fact that right-wing populists feel it necessary to repeatedly draw a clear line, in public at least, between themselves and the "extreme right" also tells us much about the extent to which both the "radical right" and "extreme right" mingle. The boundaries for political scientists, according to Copsey, have become blurred.

\section{Specific aspects of the extreme right in Slovakia}

The political scientist Mesežnikov (2011) identifies a set of factors that determine a relatively suitable social mobilization of the extreme right in Slovakia. It concerns a multi-ethnic composition of population, the unfavourable situation of the Roma minority, the aforementioned ideological and political legacy of the local fascism from the first half of the $20^{\text {th }}$ century and growing revisionist elements in the official historical science. Right-wing extremism in Slovakia is differentiated by Nociar (2012) into two players. On the one hand, a group of skinheads and "resistance groups" that operate informally and independently of political parties, with no permanent organizational structure, and, on the other hand, there are the civic organizations and political parties seeking to create permanent institutionalized right-wing extremist structures. The well-known and most successful of these latter include Slovak Brotherhood (Slovenská pospolitost') and Kotlebovci the People's Party Our Slovakia (Kotlebovci - L’udová strana Naše Slovensko, Kotlebovci - LSNS). Mikušovič (2012b) divides the Slovak extreme right according to their programmes into two basic streams: a) an ultra-nationalist stream - characterised by a strong bond to the clerical-fascist nature of the Slovak State, specifically anti-Semitism resulting from local traditions, and in particular, radical chauvinism directed especially against Hungarians; b) a neoNazi stream - defined by their allegiance to the German Third Reich and the policy of German National Socialism, including the principle of a superior Aryan race, including deeply rooted anti-Semitism and the long-term denial of the Holocaust.

Kotleba's political party is characterised by its attachment to Ludaks' ideology, ideas and ideology the Slovak State as a Slovak version of fascism, aspirations to rehabilitate its representatives, strong resistance against Hungarians who are blamed for their aspirations to integrate the southern areas 
The entry of an extreme right party into the Slovak parlament...

of Slovakia, and anti-Semitism. Further, it is anti-American, rejects the EU, NATO and other international organizations, emphasizes morality and "Christian" values that, according to them, the modern culture threatens and destroys, aspires to enter into politics and populistic rhetoric, and also resists and rejects liberalism (Mlynárčiková et al., 2010).

\section{LSNS}

\section{Ideological and institutional predecessors of the party Kotlebovci -}

The resistance groups have a tendency, according to Nociar (2012), to support official nationalist parties. Since 2003, when the public awareness of the Slovak Brotherhood (SP) and its later political branches arose, a continuous growth in the political support of these organizations has been seen.

The Slovak Brotherhood (SP) has been the best-known organization among the Slovak ultra-right groups. Due to its appearance in the media, it has become a synonym for the Slovak right-wing extremism as such. It has gained a significant status by organizing torch marches and commemorative events in Slovak cities, in which its members marched dressed in dark-blue uniforms. However, lately it has also entered into the election competition and its programme has become more sophisticated. The programme concept of the new political party was indicated by its leader, Marian Kotleba, in his speech in Modra, in which he refutiated parliamentary democracy, and embraced corporatist directions of the war-time Slovak State in connection to solving the Jewish question. He talked about driving the Jews out of the country as the optimal solution to the Jewish question. The programme was introduced to the public at the $66^{\text {th }}$ anniversary of the creation of the Slovak State in Bratislava. The document, with the goal to assault communists, liberals and Zionists and build the welfare of the "beloved Slovak State", presents the conditions of the Slovak ultra-right as a unique and comprehensive ideological starting point to change the political system and eliminate liberal democracy. The SP-NS People's Programme has encoded principles of chauvinism, anti-Semitism, discrimination and inequality. One of the fundamental programme principles of this political party is neo-Ludakism. SP-NS is based on the tradition of the war-time Slovak State as the first independent state of the Slovak nation, but it clearly focuses on its political system that, according to SP-NS, approached a lot the corporatist arrangements that they pursue (Mikušovič, 2007).

Kotleba's sharp anti-Semitic statements have also been documented. On 14 March 2004 in Bratislava, in one of his lesser known speeches, through a quote from L'udovít Štúr about the Jews as an alien nation, he claimed that "Štúr talked about these devils in human skin." Photographs of the Nazi henchman Rudolf Hess were found among the candidates of the LSNS and they took photographs with the insignia used by the SS forces (Mikušovič, 2013). 
According to Nociar (2012), the ideology of the Slovak Brotherhood combines the traditional issues of extreme nationalism, racism, anti-Semitism, neo-fascism and in some aspects also neo-Nazism. It opposes pluralism and liberal economy, promotes economic paternalism, and supports nationalism, xenophobia, and authoritarianism. It embraces conspiracy theories and expresses nationalist-populist requirements. In relation to ethnic minorities, the Slovak Brotherhood proposes to apply the principle of reciprocity so that political representation of a specific national minority reflects the representation of the Slovak minority in the country from which the minority comes. These arrangements would mean an actual inequality in the weight of voices. The authors of the 2009 SP-NS programme objectives that later became the programme objectives of the new intended political party. Apart from several items new political programme is identical, there was just one major change: a call for replacement of the representative democracy with direct democracy.

The Slovak Brotherhood became a synonym of Slovak right-wing extremism as such, though eventually, the SP-NS was dissolved by the order of the Supreme Court of the Slovak Republic on 1 March 2006 (Mikušovič, 2007).

The right-wing extremist scene then, according to Nociar (2012), tried to rid itself of the skinhead image and lifestyle, and to gain wider public acceptance. Its strategy was modified. The Slovak Brotherhood drew its main attention to nostalgia for the fascist regime and stronger anti-Roma attitudes, which increased their popularity. This may be linked to a number of activities against "Roma crime" that it co-organized in summer 2009. The public support encouraged the SP to carry out further mobilization activities, mostly on the anti-Roma topic. Encouraged by the public support, Marian Kotleba, the former SP-NS leader, became one of the main figures of the demonstrations.

\section{Kotlebovci - LSNS: Populistic radicals or (neo)fascist extremists?}

The People's Party Our Slovakia (Ludová strana Naše Slovensko, LSNS) emerged, according to Nociar (2012), as a result of the aforementioned aspirations of the SP-NS to revive its activities. In the late summer of 2009 the intention to establish a new political entity called Our Slovakia (Naše Slovensko) and take part in the upcoming parliamentary elections was announced. Its programme objectives were almost identical to the ones from January 2009. T

The LSNS was founded in the beginning of 2010. Its website contains the slogan "with courage against the system". They call Roma "anti-social parasites" who abuse the social system and are a source of a high crime rate. However, the LSNS leaders reject such attributes and seek to reclassify the term extremism by introducing the term "Gypsy extremism". 
The second major theme in the LSNS rhetoric is its criticism of and attempts to discredit established political parties and elites, against which the party tries to adopt a tough stance, presenting the parties and the elites as spoiled, removed from the reality, and indifferent to the problems of ordinary citizens. Anti-Semitism is not addressed as much as in the SP-NS. The LSNS programme, presented as election manifesto for the 2010 and 2012 parliamentary elections, in no way represented an elaborate political programme. Rather it included populistic slogans in the spirit of anti-Roma rhetoric, social chauvinism, paternalism, with the emphasis on law and order, and criticism of political leaders in the country and their foreign policy (Nociar, 2012).

To this they add that they are in the position of martyrs, suffering for their beliefs under police truncheons. Definitely the main issue is racism, through which they won sympathy from some members of the majority population in the locations with segregated Roma settlements. The LSNS representatives systematically look for social conflicts and striking crime cases to which they later attach racist undertones (Antifa.cz, 2010).

In the 2010 parliamentary elections the party with their then-separate candidate list won $1.33 \%$ of the votes (33,724 votes) and in the 2012 early elections their result increased to $1.58 \%$ (40,460 votes). After the 2012 elections, the LSNS, according to their website, "names the most serious problems by their correct names and is not afraid of putting large patches over large holes" (Naseslovensko.net, 2013). With the party slogan "For decent people! Against parasites!", the L'SNS started to gradually focus its manifesto on sharp criticism of the situation in the country. On the one hand, they criticised the behaviour of established political parties and government officials and their policies directed against "decent Slovaks", and on the other hand, they sharply criticised the free-rider problem of the Roma population and "the Gypsy extremism and terror". This agenda was disseminated at meetings in the locations which have problems with Roma settlements or individual Roma inhabitants (Kluknavská, 2012).

The party's first-ever election victory may have been Marian Kotleba's victory in the second round of the 2013 regional elections. In that election he was elected as President of the Banská Bystrica Self-Governing Region with $71,397(55.53 \%)$ votes of all eligible votes cast (Štatistický úrad Slovenskej republiky, 2020). The influence of this election was soon evident. The periodical Bystrický kraj, published by the Banská Bystrica regional government, led by Marian Kotleba, featured an article on debt reduction with an illustrative picture taken from an anti-Jewish cartoon. In the original cartoon there is also a text saying "With Jews You Lose" next to the character. The Banská Bystrica regional government began publication of he letter-box newspaper Bystrický kraj soon after the members of the regional parliament did not approve a budget item to publish the former periodical Náš kraj. This latter publication featured articles that mentioned Tiso's regime in a positive 
light and highlighted the period of the war-time Slovak State, labelled by the newspaper as "the anniversary of a fulfilled dream" (Poláš, 2015).

Further, the Governor of the Banská Bystrica Self-Governing Region, Marian Kotleba, hung out two black flags on the day of celebrating the Slovak National Uprising, 29 August 2015. Marian Kotleba has a clear stance towards the uprising. In the past he branded it as a red coup and labeled partisans as bandits. Several months before that, he ignored a resolution of members of the regional parliament and did not go to lay a wreath in Kremnička to commemorate the 750 victims of war, mostly the Jews, who died there (Vražda, 2015).

During the period before the 2016 parliamentary elections, Kotleba's party also came to the public attention by holding meetings in different cities in Slovakia against the Islamisation of Europe, which had a connection with the ongoing migration crisis in Europe. The largest march took place in the capital city of Bratislava on 20 June 2015. During the anti-immigration demonstration, Kotleba provocatively wished the crowd a "nice white day". Later, the EU flag was torn and burned. The rest of the speakers threatened parliament politicians with "settling the score with them" or defenestration and greeted the crowd with "On Guard!" ("Na stráž!") used by members of the Hlinka Guards during the war-time Slovak State (Mikušovič, 2015).

The 2016 parliamentary election manifesto was a modification of the populist slogans. According to them, many decent families live in appalling conditions, thieves in the government supposedly enjoy unprecedented luxury, and "parasites" have everything for free. They claim that they will give short shrift to "parasites in settlements" and protect people from the "growing Gypsy terror". The manifesto continues with slogans against refugees (Naseslovensko.net, 2015).

In the parliamentary elections of March 2016, Kotleba, LSNS surprisingly won 209,779 votes (8.04\%) and gained 14 out of 150 seats in the Slovak parliament (Štatistický úrad Slovenskej republiky, 2020). This brought a significant reaction not only in the Slovak media, but in the public and among politicians or experts.

Only a few days after the success in the parliamentary elections, on 14 March 2016, Kotleba's MPs publicly commemorated the anniversary of the war-time Slovak State. The MPs laid flowers on Tiso's grave and sang the Slavic song "Hey Slovaks" the national anthem of the Slovak State (Šnídl, 2016). On the same day, Banská Bystrica's Governor and member of the national parliament, Marian Kotleba, gave an instruction to unexpectedly end a stage play in Brezno. He did not like overtly emotional expressions in the artistic text. The impact of the official censorship was revealed before the performance. The office asked the actors to change or remove overly emotional and indecent expressions (Vražda, 2016). This was not the first time. In 2015 
Kotleba thwarted a festival of a longstanding tradition, allegedly because it was about "decadent arts". The Head of the Office of the Banská Bystrica SelfGoverning Region Milan Uhrík (currently a Kotleba's party member of European Parliament) expressed the then official position that the shows of Divadlo Štúdio Tanca often go well beyond the borders of decency and morality (Kysel', 2015).

The head of L'SNS, Marian Kotleba, seemed to demonstrate his admiration for fascism again. As a member of parliament, he sent a letter to Andrej Danko, who was, at the time, Chair of the Parliament, requesting that he ask the members of parliament to observe a minute's silence in their session on Monday 18 April 2016 to honour the memory of President of the war-time Slovak State, Jozef Tiso. In the letter, he writes that, 69 years ago on 18 April, a shameful judicial murder of the first president of the Slovak Republic and priest Jozef Tiso took place (Pacherová, 2016).

Since April 2016 Kotleba's party introduced the so-called patrols on trains. Originally, they were supposed to be the vanguard of a militia organized as a response to the crime rate on trains. The groups typically consisted of three shaven-headed men wearing green T-shirts with the party's logo. These men would board trains and pretend to be officers of law and order, posing as guardians protecting the riders from "antisocial elements", but in fact, they only raised fears among decent passengers. On trains the patrols draw particular attention to the Roma (Dugovič, 2016).

In addition, the Kotleba's party MPs decided to spend the money from the state budget to form militias. In response to this, the other MPs started to work on amending the legislative act on political parties. Political parties are likely to be prohibited from arming and forming their own armed forces. Similarly, they should also be prohibited from spending public funds on elections (TASR, 2016).

Furthermore, the blogger Ján Benčík (currently a member of Slovak parliament) regularly demonstrates that many exponents of Kotleba's party do not have a problem in publicly venerating (mostly on social networks) Hitler or in laying claim to the legacy of the Third Reich. Ján Benčík has become a "menace" to the L'SNS and because of him the party members and sympathisers have cancel their accounts on social networks and are ashamed to admit that they like the posts that they had previously shared (Kysel', 2016).

The party also has foreign contacts outside Slovakia. For example, on their official website, in their report from their party meeting on 18 June 2016, they write that the formal part of the meeting included participation and speeches from foreign guests, in particular, the representatives of the Italian party Forza Nuova, the Greek Golden Dawn, the NPD from Germany and DSSS from the Czech Republic (Naseslovensko.net, 2016). All these parties may be seen as far-right groups. How the Slovak right-wing scene will further 
develop remains a hypothetical question. Activities of LSNS continue in similar scandalous form. Almost every day there are new problems that are presented in the media. In the autumn of 2016, the Slovak Parliament approved an amendment of the anti-extremist laws. Within the Ministry of Interior, a new department to combat extremism has been created as well as new expert department of the Ministry of Justice, which deals with political and religious extremism.

However, terms such as neo-fascism or neo-Nazism are from the field of political science, not legal concepts. From a legal point of view, it is very difficult to characterize the ideology of the movement and to point out its wellhidden neo-Nazi character (Drábik, 2019).

The proposal for the dissolution of a political party L'SNS was submitted to the Supreme Court by General Prosecutor Jaromír Čižnár in May 2017. According to the court in 2019 , the most important element in the threat to democracy was element of immediacy. The Court found that the risk is not sufficiently imminent, as a political party LSNS has not enough deputies in parliament to passed legislation that could threaten democracy. The indictment's arguments were based on the fact that criminal proceedings were being conducted with the party's chairman (Kotleba) and two members of parliament from LSNS. According to the court, this could not be considered as an aggravating circumstance in the decision. The court said that ruled on the dissolution of the L'SNS as an administrative court and not as a criminal court. According to the court, the action was insufficiently substantiated (TA3 \& TASR, 2019).

Marian Kotleba ran for the post of Slovak president in 2019 and in the first round of elections he finished in 4th place with about 223,000 votes, which represented $10.39 \%$ of the votes of participating voters. After the parliamentary elections in 2020 his party entered parliament with a 230,000 votes $(7.97 \%)$ (Štatistický úrad Slovenskej republiky, 2020). The party continues a similar policy which it represented in the election period in 2016-2020.

Kotleba is guilty since October 2020 of supporting and promoting a movement aimed at suppressing fundamental rights and freedoms. He was sentenced to four years and four months in prison. The judgment is not final. If the Supreme Court upheld the judgment of the Specialized Criminal Court, Kotleba would also lose his parliamentary mandate. Kotleba allegedly handed over checks in the amount of 1,488 euros as part of his charitable activities, which according to the indictment was not a coincidence. The prosecutor was convinced that the amount should be read separately as numbers 14 and 88 . The first is a reference to the 14-word statement of the American racist David Lane: "We must protect the existence of our people and the future of white children." The number 88 refers to the eighth letter of the alphabet - H. The two eights are two H, so a reference to the Nazi salute "Heil Hitler!" Court stated that the amounts on the checks referred to neo-Nazism. As one of the pieces of 
The entry of an extreme right party into the Slovak parlament...

evidence, the court used a donation contract for the amount of 1,488 euros, which, according to the judge, showed that the donor was not LSNS, but Marian Kotleba personally. According to the court, the numbers themselves have no meaning, but according to the court, such numbers have meaning only in connection with other circumstances that prove signs of extremism. The court spoke extensively about the extremist background of the LSNS and mentioned in particular the abuse of persons to whom sums of 1,488 euros were handed over. It was not about handing over aid, but about abusing people to promote "perverted fascist ideas." According to the prosecutor's office, it was not accidental when Kotleba handed over the checks. It happened on March 14, 2017 on the anniversary of the establishment of the Slovak state. The event took place in the auditorium and the footage shows a portrait of Jozef Tiso, the president of this state and a convicted war criminal (Mikušovič, 2020).

The historian Jakub Drábik (2016) wrote an extraordinarily interesting article for the Slovak opinion-forming daily Denník N after the 2016 elections entitled "Is Marian Kotleba really a fascist?". The leitmotiv of the article is a finding that what makes a fascist a fascist are not external signs but his mind sets. Kotleba and his supporters clearly condemn the existing political system and assume the role of an "anti-system movement", just as all fascist parties in the world, in the past and present. The responsibility for the "ill-fated" state of society/ethnic group/nation in the eyes of fascists has always been carried by a real or invented groups, which, according to them, the nation/ethnic group/society/state they belong to or feel they belong to, must be "cleansed". In the LSNS doctrine there are several internal and external enemies: the current elected and corrupted government and in general any politicians of "standard" political parties, the Roma ethnic group or the Jews. European civilization is according to LSNS threatened by Islam and refugees from outside. Kotleba wants to clean Slovakia of all that and impose "order". And this is what makes him, according to Drábik, a fascist. Anyone who claims that he has changed, especially with his softer rhetoric and that he no longer marches in a uniform holding a garden torch, should draw a distinction between what Kotleba says and what he really thinks, or what he hides behind his words. Drábik refers to the British historian Roger Eatwell who, in the early 1990s, pointed out a significant difference between the esoteric (what fascists debate among themselves, in close circles) and exoteric (what they consider appropriate to say in public) appeal of fascist parties and movements.

\section{Conclusion}

Political party Kotlebovci - LSNS, not only on the basis of history and genealogy, programme and ideological platform, but also real political acts, and proven cooperation with similar parties, may be labelled as fascist. The Slovak initiative Stop Fascism believes that looking at the true intentions of the election manifesto of this party is the same as looking at promises for the 
genocide of the Jews in the manifesto of Hitler's NSDAP. The historical development of the LSNS, the speeches of its present or former candidates, the statements of its MPs and their overall activities at this time quite clearly show that the L'SNS is extremist and fascist. This initiative summarised their beliefs in several points: Marian Kotleba is close to the hard-core neo-Nazi scene. In the past he personally supported events held by the extreme right. In the L'SNS candidate list, LSNS members include persons with the neo-Nazi past and views. L'SNS is the only party to give "the elite" of the Slovak neo-Nazi scene space in its candidate list - from Juden Mord's frontman Rastislav Rogel to Marián Magát, a person who wishes Adolf Hitler a happy birthday and brands him as a splendid person, peacemaker and statesman. Magát has long laid claim to the legacy of the totalitarian fascist Slovak State and its ideology. The party has open speeches of anti-Semitism, racism, and they call Roma Gypsy extremists and parasites. Marian Kotleba has, in his political campaign, openly expressed anti-Semitism. In order to avoid prosecution, he frequently brands the Jews as Zionists, though he was more open in some of his older speeches. He has never distanced himself from those speeches saying, "I am still the same Kotleba" (Stopfašizmu.sk, 2016).

According to Kluknavská and Smolík (2016) Kotleba’s political party is most determined extreme right party building upon issues of high political relevance, seizing the political and cultural opportunities which have opened up to it. Kotlebovci - LSNS altered its discourse to anti-establishment and antiminority framing and has been gradually successful in terms of mobilization and diffusion of nationalistic and xenophobic sentiments in some parts of population. L'SNS is not so much an anti-establishment political party, it is primarily an anti-systemic, extremist political party. LSNS intention is to replace the existing socio-political system with another in which the basic features of a liberal-democratic political regime, a free market economy and an open, culturally, ethnically and religiously diversified society are absent (Gyarfášová - Mesežnikov, 2016).

Despite the decision of the Supreme Court not to dissolve the political party LSNS, more sophisticated appearance and opening such topics, which are the agenda of other political entities, the ideological connection to the predecessors is noticeable. Members of the National Council of the Slovak Republic for Kotleba - LSNS (Milan Mazurek, Stanislav Mizík) are being prosecuted for racist statements against Roma, or against citizens of Slovakia of Jewish origin. At the same time, the members of the political party and the leader Marian Kotleba did not distance themselves from their previous statements promoting Nazism, fascism, denying the Holocaust and despising the Slovak National Uprising (Vasil'ková, Androvičová, 2019).

The Supreme Court concluded that the party's SP-NS activities as predecessor of LSNS were in conflict with the applicable legislation. The most critical point was the People's Program, in which the party called for the 
creation of a corporatist state. It is about effectively restricting the right to vote of some citizens and creating an undemocratic political system (Drábik, 2019).

The expert on the Slovak war state and historian Ivan Kamenec claims that Kotleba has not changed and is not moderate even today. Kamenec knew the programme and other documents of the banned Slovak Brotherhood. The current LSNS manifesto is similar, according to him, but in several regards and verbal expressions Kotleba is more cautions, sophisticated. He thinks that the LSNS, contrary to its predecessor, has not changed. However, Kotleba is left with his own anti-Roma, anti-Zionist (which is taken to mean anti-Semitic) themes, and in particular, unfulfillable promises of fast and simple solutions to all contemporary problems of society. Kamenec personally considers Kotleba to be a fascist because he took over some the World War II elements of Slovak fascism. Through intolerance, violence, promises of simple solutions, what he pursues is fascism. As a specific example of fascism, he organized marches to Roma settlements. Their sole objective was intimidation. And intimidation is, according to Kamenec one of the key hallmarks of fascism (Mikušovič, 2016).

Kotleba's and his political party L'SNS previous activity and constant attacks on democracy and the democratic system, praising undemocratic regimes, declaring an effort to achieve an alternative to the current decadent era, a new era and brilliant tomorrows, international cooperation with similar movements, racist and anti-semitic expressions and the use of neo-semitic expressions point to the ideology of the party. The LSNS is a neo-Nazi party, belonging to a larger family of fascist movements (Drábik, 2019).

Coincidentally the Slovak society is at the stage that it is for various reasons willing to support these and similar subjects, its candidates and manifesto, in elections and demonstrations in a significant number, as it used to be in the past in Slovakia, but also in the democratic political systems of liberal democracies. Most members of society, as well as the political and intellectual elite, should be aware of the rise of extremism. The political and intellectual elites have a slightly greater political and moral responsibility for the situation. Besides the actual work for the benefit of the citizens, public welfare and society as such, political and intellectual elites should clearly promote and appeal to the values and principles of democracy, on the other hand, take practical steps also in legislation, education and moral appeals. 


\section{Bibliography}

Antifa.cz. (2010, May 11). Slovenskí neonacisti mieria do parlamentu, Retrieved from http://www.antifa.cz/content/slovenski-neonacistimieria-do-parlamentu

Beyme, K. V. (1985). Political parties in Western Democracies. Aldershot: Gower.

Copsey, N. (2013). Fascism... but with an open mind' Reflections on the Contemporary Far Right in (Western) Europe. Fascism, 2 (1), 1-17.

Denník N. (2016). Minúta po minúte. Denník N. Retrieved form https://dennikn.sk/minuta/416220/

Drábik, J. (2014). K problematike definície pojmu fašizmus, „nového konsenzu“ a vývoja v bádaní o fašizme. Historický časopis, 62 (4), 695-718.

Drábik, J. (2016). Je Marian Kotleba skutočne fašista? Denník N. Retrieved from https://dennikn.sk/398951/marian-kotleba-skutocne-fasista/

Drábik, J. (2019). Fašizmus. Bratislava: Premedia.

Drulák, P. et al. (2008). Jak zkoumat politiku. Kvalitativní metodologie v politologii a mezinárodních vztazích. Praha: Portál.

Dugovič, M. (2016). Kotlebove hliadky sú stále vo vlakoch, polícia striehne a minister dopravy len sleduje situáciu. Denník $N$. Retrieved from https://dennikn.sk/500270/kotlebove-hliadky-su-stale-vo-vlakochpolicia-striehne-minister-dopravy-sleduje-situaciu/

Eremina, N. \& Seredenko, S. (2015). Right Radicalism in Party and Political Systems in Present-day European States. Newcastle upon Tyne: Cambridge Scholars Publishing.

Gallagher, M. \& Mair, P. \& Laver, M. (Eds.). (2005). Representative Government in Modern Europe. Boston: McGraw Hill.

Gyarfášová, O. \& Mesežnikov, G. (2016). Súčasný pravicový extrémizmus a ultranacionalizmus na Slovensku. Stav, trendy, podpora. Bratislava: Inštitút pre verejné otázky.

Hanzel, I. (2009). Kvalitatívne, alebo kvantitatívne metódy v sociálnych vedách? Filozofia, 64 (7), 646-657.

Hloušek, V. \& Kopeček, L. (2010). Politické strany. Původ, ideologie a transformace politických stran v západní a středni Evropě. Praha: Grada Publishing, 2010.

Ignazi, P. (1995). The re-emergence of extreme right-wing parties in Europe. Reihe Politikwissenschaft / Institut für Höhere Studien, Abt. Politikwissenschaft, 21. Wien: Institut für Höhere Studien (IHS), 1 14.

Ignazi, P. (2003). Extreme Right Parties in Western Europe. Oxford: Oxford University Press.

Karapin, R. (1998). Radical-Right and Neo-Fascist Political Parties in Western Europe. Comparative Politics, 30 (2), 213-234. 
Kluknavská, A. \& Smolík, J. (2016). We hate them all? Issue adaptation of extreme right parties in Slovakia 1993-2016. Communist and PostCommunist Studies, 49 (4), 335-344.

Kluknavská, A. (2012). Krajne pravicové strany v parlamentných vol'bách 2012 na Slovensku. Rexter, 10 (1), 1-35.

Kopeček, L. (2007). The Far Right in Europe. Central European Political Studies Review, 9 (4), 280-293.

Kysel', T. (2015). Kotleba zmaril festival s dlhoročnou tradíciou, vraj ide o dekadentné umenie. Aktuality.sk. Retrieved from http://www.aktuality.sk/clanok/301398/kotleba-svojou-necinnostouzmaril-festival-s-niekolkorocnou-tradiciou/

Kysel', T. (2016). Bloger ide po krku kotlebovcom: Sú nebezpeční, ale zastrašit' sa nedám. Aktuality.sk. Retrieved from http://www.aktuality.sk/clanok/335646/bloger-ide-po-krkukotlebovcom-su-nebezpecni-ale-zastrasit-sa-nedam/

Mair, P. \& Mudde, C. (1998). The Party Family and Its Study. Annual Review of Political Science, 1 (1), 211-229.

Mareš, M. (2003). Pravicový extremismus a radikalismus v $\check{C} R$. Brno: Barrister \& Principal.

Mesežnikov, G. (2011). Politický kontext činnosti radikálnych nacionalistov a pravicových extrémistov na Slovensku. In: Mlynárčiková, V. \& Gáborová, Z. (Eds.). Tí praví. Zborník príspevkov z konferencie o pravicovom extrémizme (pp. 9-16). Bratislava: Nadácia otvorenej spoločnosti - Open Society Foundation.

Mikušovič, D. (2015). Demonštranti proti utečencom hádzali do l'udí kamene a ničili policajné autá. Denník $N$. Retrieved from https://dennikn.sk/165440/demonstranti-proti-utecencom-hadzali-doludi-kamene-nicili-policajne-auta/

Mikušovič, D. (2007). Slovenská pospolitost' včera a dnes. Rexter, 6 (1), 1-24. Mikušovič, D. (2012a). Podobnosti a rozdiely medzi slovenskou a mad'arskou krajnou pravicou. In Danilov, S. \& Mikušovič, D. (Eds.). Milovaní a nenávidení. Podobnosti a rozdiely medzi slovenskou a mad'arskou krajnou pravicou (pp. 22-29). Bratislava: Inštitút pre medzikultúrny dialóg.

Mikušovič, D. (2012b). Slovenská perspektíva. Ideologická a organizačná charakteristika slovenskej krajnej pravice. In Danilov, S. \& Mikušovič, D. (Eds.). Milovaní a nenávidení. Podobnosti a rozdiely medzi slovenskou a mad'arskou krajnou pravicou (pp. 7-11). Bratislava: Inštitút pre medzikultúrny dialóg.

Mikušovič, D. (2013). Najpresnejšie označenie Kotlebu? Sympatizant fašizmu. Sme. Retrieved from http://domov.sme.sk/c/7022154/najpresnejsieoznacenie-kotlebu-sympatizant-fasizmu.html\#ixzz4EPe23cW6

Mikušovič, D. (2016). Historik Kamenec: Kotleba dnes nie je umiernený, len nehovorí veci naplno. Denník $N$. Retrieved from https://dennikn.sk/404124/historik-kamenec-kotleba-dnes-nieumierneny-nehovori-veci-naplno/ 
Mikušovič, D. (2020). Kotleba je vinný z propagácie fašizmu. Sudkyňa sa pohrala s číslami - dala mu 4 roky a 4 mesiace. Denník $N$. Retrieved from https://dennikn.sk/2083767/na-sude-s-kotlebom-sa-vytiahliponozky-z-deichmanna-aj-milan-lasica-lider-lsns-si-vypocul-vinnyaj-napriek-zdrzovaniu/?ref=mpm

Mlynárčiková, V. et al. (2010). Nemaj trému z extrému. Bratislava: Nadácia otvorenej spoločnosti.

Mudde, C. (1995). Right-wing extremism analyzed. A comparative analysis of the ideologies of three alleged right-wing extremist parties (NPD, NDP, CP'86). European Journal of Political Research, 27 (2), 203224.

Naseslovensko.net. (2013). O L’udovej strane Naše Slovensko. Retrieved from http://www.naseslovensko.net/clanky/lsns_profil.htm

Naseslovensko.net. (2015). Volebný program politickej strany Kotleba Ludová strana Naše Slovensko, 10 bodov za naše Slovensko! Retrieved from http://www.naseslovensko.net/wpcontent/uploads/2015/01/Volebn\%C3\%BD-program-2016.pdf

Naseslovensko.net. (2016). Snem Ludovej strany Naše Slovensko. Retrieved from http://www.naseslovensko.net/nasa-praca/snem-ludovej-stranynase-slovensko-2016/

Nociar, T. (2016). Politológov sprievodca „terminologickým chaosom“: Terminológia, charakteristika a konceptualizácia krajne pravicovej ideologickej rodiny. Rexter, 14 (1), 44-91.

Nociar, T. (2012). Right-Wing Extremism in Slovakia. Berlin: Friedrich-EbertStiftung, Dep. for Central and Eastern Europe.

Pacherová, S. (2016). Minúta ticha za vojnového zločinca Tisa v parlamente nebude. Pravda. Retrieved from http://spravy.pravda.sk/domace/clanok/390015-poslanca-smerupoburila-ziadost-kotlebu-o-minutu-ticha-za-tisa/

Poláš, M. (2015). Kotleba má v župných novinách obrázok z antisemitskej karikatúry. Mediálne.Trend.sk. Retrieved from http://medialne.etrend.sk/tlac/kotleba-ma-v-zupnych-novinachobrazok-z-antisemitskej-karikatury.html

Rybáŕ, M. (2003). Stranícke rodiny a prípad Slovenska: Niekol'ko teoretických poznámok. Politologický časopis, 10 (3), 275-281.

Slovenská pospolitost'. (2013). O stránke. Retrieved from http://pospolitost.wordpress.com/about

Stop fašizmu. (2016). Prečo je L'SNS extrémistická strana. Retrieved from http://stopfasizmu.sk/lsns/

Šnídl, V. (2016). Traja Kotlebovi poslanci sa poklonili Tisovi. Máte odvahu, chválil ich kňaz. Denník $N$. Retrieved from https://dennikn.sk/405577/traja-kotlebovi-poslanci-sa-poklonilitisovi-mate-odvahu-chvalil-knaz/

Štatistický úrad Slovenskej republiky. (2020). Vol'by a referendá. Retrieved from https://volby.statistics.sk/ 
TA3 \& TASR. (2019, April 29). Riziko nie je dost’ bezprostredné. Prečo súd nerozpustil LSNS. Retrieved from https://www.ta3.com/clanok/1153823/riziko-nie-je-dostbezprostredne-preco-sud-nerozpustil-lsns.html

TASR. (2016, May 25). Poslanci dnes posunuli do druhého čítania jediný opozičný návrh.

Retrieved

from

http://www.teraz.sk/slovensko/stranam-zrejme-zakazuozbrojovanie/198576-clanok.html

Vasil'ková, A. \& Androvičová, J. (2019). Príčiny nárastu podpory pravicového radikalizmu a extrémizmu na Slovensku: príklad politickej strany Kotleba-L'SNS. Central European Journal of Politics, 5 (1), 71-99.

Vražda, D. (2015). SNP: Kotleba vyvesil na úrad čierne vlajky. Denník $N$. Retrieved from https://dennikn.sk/226559/snp-kotleba-vyvesil-uradcierne-vlajky/

Vražda, D. (2016). Kotleba uprostred hry zrušil divadelné predstavenie. Denník $N$. Retrieved from https://dennikn.sk/407006/kotleba-zatiahol-oponupocas-divadelneho-predstavenia-zrusil-ho-uprostred/

Žúborová, V. (2011). Prejavy personalizácie líderstva: perspektívy slovenských straníckych lídrov vo vzt’ahu k medializácii. Central European Political Studies Review, 13 (4), 399-419. 
